\title{
Hegemonic Masculinity of Mamak (Uncle) to Kemenakan (Nephew) In Novel by Wisran Hadi and A. R. Rizal
}

\author{
Iswadi Bahardur ${ }^{1}$, Andayani ${ }^{2}$, Sarwiji Suwandi $^{3}$, Nugraheni Eko Wardani ${ }^{4}$ \\ Fakultas Keguruan dan Ilmu Pendidikan, Universitas Sebelas Maret, Surakarta, Indonesia \\ iswadibahardur@student.uns.ac.id ${ }^{1}$, bu anda09@yahoo.co.id ${ }^{2}$, \\ sarwijiswan@yahoo.com ${ }^{3}$, nugraheniekowardani 99@staff.uns.ac.id
}

\begin{abstract}
Matrilineal kinship in Minangkabau does not absolutely give power to women. It turns out that men still get a chance to carry out hegemony to women. Based on these problems, this study aims to examine the patterns of hegemonic masculinity manifested in the relationship between mamak (uncle) and kemenakan (niece) of women in two Indonesian novels, Orang-orang Blanti by Wisran Hadi and Perempuan Batih by A.R Rizal. This study applies descriptive qualitative methods and discussion of research problems with content analysis techniques. Analysis and interpretation of research problems are carried out with data reduction, data display, and conclusion drawing. The results showed that the hegemony of mamak's masculinity towards kemenakan (nephew) manifested in two patterns, a) intellectual and moral leadership; and b) domination (violence). Two patterns of hegemony of masculinity are carried out by male figures over female figures to exercise control in terms of regulating family inheritance rights, unilaterally regulating marriages, and regulating work areas for women. The results of this study have implications for the regulation of gender mainstreaming for women in the Minangkabau matrilineal social and cultural system.
\end{abstract}

Keywords: hegemony masculinity, mamak, Minangkabau, nephew

\section{INTRODUCTION}

Men in the Minangkabau tribe have two roles according to the provisions of matrilineal customary law[1]; [2];[3]. As long as these roles are carried out, Minangkabau men are confronted with conflicts of interest because their people practice a matrilineal culture . To maintain their existence in this dualism of roles, Minangkabau men create masculine politics in the form of cultural control[4]; [5] and demands for feminine gender compliance. In the modern era, the role of dualism has an impact on the change in the pattern of mamak leadership on nephews[6]. Changes in leadership patterns include patterns of decision making by mamak (uncle) related to inheritance rights, moral control, and mamak policies in the rules of his nephew's marriage [7]. The norms set by mamak (uncle) in the supervision of her kemenakan (nephew) have also changed to reproducible value standards to maintain their good name in society. This method reflects the hegemony of the masculine class, gender hierarchy, and the subordination of women that is prevalent in patriarchal culture [8].

Basically, leadership practices that resemble hegemony of masculinity are not in accordance with the matrilineal system in Minangkabau. Hegemony was born in a society 
based on Marxist ideology, practiced in the country's political leadership, and raised the issue of social class differences [9];[10]. In addition, hegemony of masculinity sees the problem of patriarchal culture which creates a dominant masculine gender class system over subordinate feminine gender [11]; [12];[13]. In contrast to this concept, matrilineal in Minangkabau prioritizes the role of women as bundo kanduang (mother in power)[14], recipients of family heirs, successors to lineage [15]; [16] and educators of children in the household.

The problem of masculine hegemony in the culture of the Minangkabau community does not only occur in real life. In modern Indonesian literary works the local color of Minangkabau can also be found its reflection, such as in the novel Orang-Orang Blanti by Wisran Hadi and Perempuan Batih by A.R. Rizal. The author is portrayed through the theme of the story, character conflicts, social and cultural settings, and character characters. Through the elements of the story, it can be seen that the change in the Minangkabau people's perspective on the application of cultural values and the masculine roles of mamak in the modern era has opened space for hegemonic masculinity practices[17]; [18]. Judging from the innovation and novelty of research, this research has reflected that. The tendency of previous research always highlighted the issue of hegemonic masculinity in novels set in patrilineal culture, while this study investigated the same case in novels set in matrilineal culture in Minangkabau. Therefore, research on hegemonic masculinity of mamak leadership on nephews in matrilineal society is seen as important with the following rationale, a) the existence of several Minangkabau matrilineal cultural values that remain dominated by masculine ideas; b) the power of masculine ideas in Minangkabau matrilineal culture has an impact on social practices that support the hegemony of masculinity.

\section{METHOD}

This article is the result of qualitative research using a content analysis approachc [19]; [20]. Research data sources are novels from Indonesian writers, namely Orang-Orang Blanti by Wisran Hadi andPerempuanBatih by A.R. Rizal. The research data are words, phrases, sentences, and dialogues in the Orang-Orang Blanti and PerempuanBatih novels that inflame the hegemony of mamak masculinity to nephews. Research data were collected in stages a) of reading; and b) recording. The stage of recording data or unitizing is done by marking each data unit of texts in the novel, according to the research problem. The next stage is the recording of data into classification units, with a model analysis of hegemony patterns by Gramsci[21] and the scope of hegemony of masculinity[22]. Analysis and interpretation of research problems follows the stages proposed by [23]; [24]. The stages include data reduction, data display, and conclusion drawing or verification. The stages of analysis and interpretation are then applied to the interpretation of research problems by applying Gramsci and Messersmidt hegemony studies. The results of the analysis of hegemonic masculinity patterns in the novel by Wisran Hadi and A.R. Rizal was further linked to the issue of hegemonic masculinity in the context of the Minangkabau community and people in various other countries.

\section{RESULTS AND DISCUSSION}

Based on the findings of research data in the novel Orang Orang Blanti by Wisran finished and Perempuan Batih by A.R. Rizal, there are two forms of masculinity hegemony 
carried out by mamak (uncle), namely a) hegemony of masculinity with intellectual and moral leadership patterns; and b) hegemony of masculinity with dominance leadership patterns.

\subsection{Hegemony of Mamak (Uncle) Masculinity to Kemenakan (Nephew) with Intellectual and Moral Leadership Patterns}

The mamak's masculinity hegemonic practices towards nephews with intellectual and moral leadership patterns are depicted in Perempuan Batih's novel by A.R. Rizal, which is a gender relation between a mamak (uncle) figure named Zainun and a female character named Gadis who plays a kemenakan (nephew). Gender relations formed between creating Zainun and Gadis are hierarchical, where Zainun is a superior figure and Gadis are subordinate. Zainun always demanded that Gadis follow the consensus he offered as a form of moral teaching which he considered most appropriate. Hegemonic masculinity created by Zainun proceeded through consensus related to the prohibition of working in public spaces, giving inheritance to Gadis, as well as unilaterally matching Gadis.

“Jadi perempuan pasar kau sekarang."Zainun berkunjung lagi. Laki-laki itu hanya bisa bermohon nama baiknya dijaga. "Kau kan bisa menunggu saja orang-orang yang datang membeli hasil ladangmu.Tak usah susah-susah.Itu baik pula untuk anak-anakmu. "("So you market woman now." Zainun visited again. The man can only beg for his good name to be protected. "You can just wait for the people who come to buy your produce. Do not bother. It is also good for your children.") (Rizal, 2018: 52-53).

Zainun banned Gadis being a vegetable seller outside the home. According to Zainun, selling vegetables in the public market is an inappropriate job for Minangkabau women. The reason, the work will damage the image of a mamak (uncle). Zainun emphasized his kemenakan (nephew) so as not to damage his image as a mamak (uncle). The way that can be taken to maintain the good name is to control all the actions and work of Gadis. Although Zainun was unable to carry out his full responsibilities to help the economic difficulties of his kemenakan (nephew), Zainun wanted Gadis to obey all his orders. Zainun very easily subjected the girl to follow his orders, because his kemenakan (nephew) had no strength to fight. Gadis also did not dare to put up a fight because she knew that Zainun was her mother's sibling.

\subsection{Hegemony of Masculinity Mamak (Uncle) to Kemenakan (Nephew) with a Pattern of Domination}

The pattern of hegemony of masculinity with dominance can be found in the relationship between Datuk Tuo as a mamak (uncle) and Bu Yuk as kemenakan (nephew) in Wisran Hadi's Orang-Orang Blanti novel. Gender relations formed between mamak (uncle) and kemenakan (nephew) reflect acts of oppressing and subordinating women. Datuk Tuo's domination $\mathrm{Bu}$ Yuk was taking the family's inheritance rights from Bu Yuk, and rejecting women's voting rights.

Tidak ada kata yang dapat dikatakannya. Betapa hebat pertengkaran antara nenek dengan adik laki-lakinya sendiri Datuk Tuo, untuk merebut semua tanah pusaka. Nenek mengalah menghindari perpecahan. Menerima saja apa yang diputuskan. Tanah pusaka harus dibagi. Orang Pulau yang bekerja pun dibagi. ... (There are no words to say. What a great quarrel between grandmother and her own younger brother Datuk Tuo, to seize all the inheritance land. Grandma relented avoiding division. Just accept what is decided. The inheritance must be divided. Island people who work are divided).

Datuk Tuo's leadership pattern turned into a hegemony of dominance masculinity due to two things. First, his failure to achieve the ideal masculinity superiority of mamak's role by 
means of intellectual and moral leadership. The reason is Datuk Tuo is not from among educated men. Therefore he did not have a moral and scientific discourse strategy to influence his sister in seizing inheritance. Secondly, Datuk Tuo still holds to the traditional principles of masculinity that prioritize strength and violence in achieving the ideal goals. Therefore Datuk Tuo chose violent methods in realizing his goals.

\subsection{Hegemonic Masculinity in the Minangkabau Culture and Other Culture}

The results of the analysis of the hegemonic masculinity described in the novel Perempuan Batih and Orang-orang Blanti are closely related to the context of society in various regions and countries. Related to dominating male leadership patterns can be compared to research conducted by Tanner. Minangkabau female marriages arranged by mamak (uncle) or brothers, have been found in Minangkabau society since the early 20th century. Tanner in a study entitled The Nuclear Family In Minangkabau Matrilinyy: The Mirror of Disputes[25], taking research sites in several Minangkabau regions has revealed very surprising results. Tanner has found patterns used by traditional Minangkabau families in marrying off their daughters. If there is a daughter who has entered the age of 20 years and is not married, if she does not have a mother, then her oldest brother will agree with his mother to find a future husband for the daughter. After finding a prospective husband who is deemed worthy, both in social status, and economic status, an event will be held.

Tanner stated, in some cases, the chosen prospective husband already had a wife, but that was not considered a problem. Without asking permission from the daughter to be married, the marriage process for the male family is carried out. The girl to be married usually will not refuse, because such marriages have become a tradition. In addition, Tannner also found a Minangkabau daughter's marriage at a very young age range. The case of young marriage occurred in women from Minangkabau families who lived in rural areas and did not take formal education.Tanner also stated that it is not uncommon for established economic status to cause the Minangkabau men to carry out polygamy. The phenomenon discovered by Tanner can indirectly be seen as the forerunner of masculine hegemony patterns towards femini in the Minangkabau matrilineal society. Tanner's findings in the study showed a traditional Minangkabau family view similar to the mamak leadership patterns that researchers found in Perempuan Batih's by A.R. Rizal.Other researchers, namely [26] ; [7]have also discovered the problem of social change that has an impact on masculine domination actions on women's lives in Minangkabau. In his findings, Evers stated the beginning of the 20th century, in Minangkabau there had been a social change that changed the patterns of mamak (uncle) leadership to kemenakan (nephew). The relationship between mamak and kemenakan began to drift apart because the pattern of life of the Minangkabau community had changed from a batih family to a nuclear family consisting of only fathers, mothers, and children. The facts found by Evers are closely related to the findings of Mutolib's research. Mutolib stated that the change in the pattern of mamak (uncle) leadership in various Minangkabau areas resulted in the emergence of cases of gender injustice and the struggle for women's rights by men.

Although different cultures, it turns out the hegemony of masculinity that occurs in Minangkabau society is a picture of the same thing in patriarchal society in European countries. Men use intellectual and moral abilities and the dominance of violence to dominate or destroy women's power. As illustrated in The Rainbow's by D.H Lawrence, which is set in the patriarchal culture in Poland [27]. The oppression carried out by Polish men (Tom) against women (Lidya) aims to strengthen their masculine status as head of the household. To achieve this position, Tom realizes by removing the public rights of women. In contrast, in 
Victorian society, in England, hegemony of masculinity was not only aimed at women, but also at fellow men. Upper-class men, represented by Thomas Hardy in the novel Under The Greenwood Tree, oppressed and subodinated men with lower economic and social status, as well as an attempt to control the body of the woman they liked [28]. Comparison of research results in various countries and various cultures has proven that the hegemony of masculinity does not only take place in one culture, but in many cultures and conditions of society. Associated with the case of hegemony of masculinity in the leadership of mamak (uncle) against kemenakan (nephew) in the novel Orang Orang Blanti by Wisran Hadi and Perempuan Batih by A.R. Rizal, power, power, social and economic status are also tools for superior men to subordinate women.Comparison of research results in various countries and various cultures has proven that the hegemony of masculinity does not only take place in one culture, but in many cultures and conditions of society. Associated with the case of hegemony of masculinity in the leadership of mamak (uncle) against kemenakan (nephew) in the novel Orang- Orang Blanti by Wisran Hadi and Perempuan Batihby A.R. Rizal, power, power, social and economic status are also tools for superior men to subordinate women.

\section{CONCLUSION}

Matrilineal culture is not immortal that can guarantee the achievement of an ideal life for women. Customary provisions and practices in society are still open to space for masculine gender subordinating women. From the case of the relationship between mamak (uncle) and kemenakan (nephew) in Perempuan Batih by A.R. Rizal and Orang-orang Blanti by Wisran Hadi, have revealed the fact that the hegemony of masculinity can occur from the pattern of mamak (uncle) leadership towards kemenakan (nephew). That hegemonic masculinity can be achieved through intellectual and moral leadership and domination. This achievement can be done through a series of mamak cultural masculine controls in terms of family inheritance, marriage, and the regulation of work areas for nephews. This researcher's findings certainly become a new knowledge that can be implicated as a study material by stakeholders in the Minangkabau community. The formulation of policies on gender mainstreaming in the public sphere, especially in Minangkabau, can review the findings of this study, as a reference for formulating new policies that are more friendly to the struggle to eliminate all forms of hegemony by masculine gender.

\section{REFERENCES}

[1] T. Kusniarti, "CULTURE OF MASCULINITY IN MATRILINEAL COMMUNITY,” J. Innov. Stud. Character Educ, vol. 2, no. 1, pp. 153-161, 2018.

[2] C. Handrianto, "The Roles of Matrilineal System Towards Integrating Religious and Cultural Values in Minangkabau Community Abstract This paper looks at one of the unique cultures of Indonesia, the Minangkabau, in West Sumatera Province. Minangkabau is known as one of," J. Ilm. Peuraden, Int. Soc. Sci., vol. 5, no. 3, pp. 273 386, 2017.

[3] N. Syahrul, "Peran dan Tanggung Jawab Mamak dalam Keluarga: Tinjauan terhadap Novel Salah Asuhan Karya Abdoel Moeis," Metasastra, vol. 10, no. 1, pp. 34-44, 2017.

[4] Z. Arifin, "Buru Babi: Politik Identitas Laki-laki Minangkabau," HUmaniora, vol. 24, no. 1, pp. 29-39, 2012.

[5] Z. Arifin, "Bundo Kanduang (hanya) Pemimpin di Rumah gadang," Antropol. Indones., vol. 34, no. 2, pp. 124-133, 2013.

[6] T. H. Putra and R. Supanggah, "Memudarnya Wibawa Ninik Mamak sebagai Urang Nan 
Gadang Basa Batuah di Minangkabau," Gelar J. Seni Budaya, vol. 15, no. 2, pp. 122-131, 2017.

[7] A. Mutolib, Yonariza, Mahdi, and H. Ismono, "Gender inequality and the oppression of women within minangkabau matrilineal society: A Case study of the management of ulayat forest land in nagari bonjol, dharmasraya district, west sumatra province, Indonesia," Asian Women, vol. 32, no. 3, pp. 23-49, 2016.

[8] Y. Djalius, “Minangkabau Women And Change," Sarjana, vol. 25, no. 3, pp. 161-174, 2010.

[9] N. Wedgwood, “Connell's Theory of Masculinity - Its Origins and Influences on the Study of Gender," J. Gend. Stud., vol. 18, no. 1, pp. 329-339, 2009.

[10] R. Connell, "Masculinity research and global change," vol. 1, 2012.

[11] O. Drianus, "Hegemonic Masculinity: Wacana Relasi gender dalam Tinjauan Psikologi Sosial," Psychosophia J. Psychol. Reli. Humanit, vol. 1, no. 1, pp. 36-50, 2019.

[12] H. Gurkan and A. Serttas, "The Representation of Masculinity in Cinema and on Television: An Analysis of Fictional Male Characters," Eur. J. Multidiscip. Stud., vol. 2, no. 5, pp. 402-408, 2017.

[13] B. D. Kivel and C. W. Johnson, "Consuming Media, Making Men: Using Collective Memory Work to Understand Leisure and the Construction of Masculinity," J. Leis. Res., vol. 41, no. 1, pp. 110-134, 2009.

[14] Y. Djalius, "Minangkabau Woman and Change," Sarjana, vol. 25, no. 3, pp. 161$174,2010$.

[15] D. Fatimah, "Implementation Overview of Minangkabau Society's life Philosophy on the Custom House Interior Plan," Adv. Soc. Sci. Educ. Humanit. Res, vol. 225, no. Icobest, pp. 147-151, 2018.

[16] P. Aswirna and F. Reza, "Man's Without Power: Gender Paradigm in West Sumatera," Asian J. Indig. Stud, vol. 1, no. 1, pp. 46-56, 2015.

[17] A.R. Rizal, Perempuan Batih. Jakarta: Laksana, 2018.

[18] W. Hadi, Orang-orang Blanti. Padang: Citra Budaya Indonesia, 2000.

[19] K. Krippendorff, Content Analysis: An Introduction to its Methodology. London: SAGE Publications, Inc, 2004.

[20] J. Saldana, Fundamentals of Qualitative Research: Understanding Qualitative Research. London: Oxford University Press, 2011.

[21] J. V Femia, Gramsci's Political Thought: Hegemony, Consciousness, and the Revolutionary Process. Oxford: Glarendon Press, 1980.

[22] J. W. Messerschmidt, Hegemonic Masculinity: Formulation, Reformulation, and Amplifications. London: Rowman \& Littlefield, 2018.

[23] J. W. Creswell, Research Design: Qualitative, Quantitative and Mixed Methods Approaches. Sage Publications, 2014.

[24] N. Walliman, Research Methods: The Basics. New York: Routledge, 2010.

[25] N. M. Tanner, "The Nuclear Family in Minangkabau Matriliny: The Mirror of Disputes," Bijdr. tot Taal-, Land-en Volkenkd, vol. 138, no. 1982, pp. 129-151, 2016.

[26] Evers H, "Changing Patterns of Minangkabau Urban Land-Ownership," Bijdr. tot Taal, vol. 131, no. 1, pp. 86-110, 1975.

[27] A. Subrayan, "Representation of Hegemonic Masculinity in D . H Lawrence's The Rainbow," Int. J. Stud. English Languange Lit., vol. 3, no. 12, pp. 18-21, 2015.

[28] A.N. Wardani, "Hegemoni Maskulinitas dalam Under The Greenwood Tree Karya Thomas Hardy," SATWIKA J. Kaji. Budaya dan Perubahan So, vol. 2, no. 2, pp. 69-78, 2018. 
